\title{
Article \\ Connecting the Lab and the Field: Genome Analysis of Phyllobacterium and Rhizobium Strains and Field Performance on Two Vegetable Crops
}

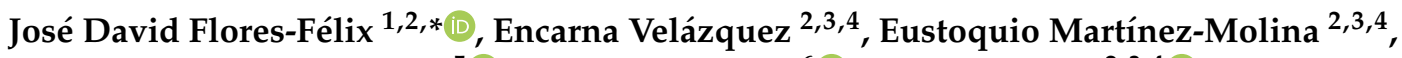

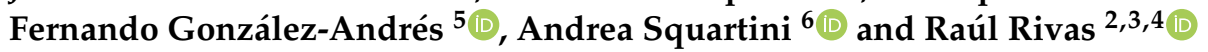 \\ 1 CICS-UBI-Health Sciences Research Centre, University of Beira Interior, 6201-506 Covilhã, Portugal \\ 2 Departamento de Microbiología y Genética, Universidad de Salamanca, 37007 Salamanca, Spain; \\ evp@usal.es (E.V.); emm@usal.es (E.M.-M.); raulrg@usal.es (R.R.) \\ 3 Instituto Hispanoluso de Investigaciones Agrarias (CIALE), Universidad de Salamanca, \\ 37185 Villamayor, Spain \\ 4 Unidad Asociada USAL-CSIC (IRNASA), 37008 Salamanca, Spain \\ 5 Instituto de Medio Ambiente, Recursos Naturales y Biodiversidad, Universidad de León, \\ Avenida de Portugal, 41, 24071 León, Spain; fgona@unileon.es \\ 6 Department of Agronomy, Food, Natural Resources, Animals and Environment, DAFNAE, \\ University of Padova, Viale dell'Università 16, 35020 Legnaro, Italy; squart@unipd.it \\ * Correspondence: jdflores@usal.es; Tel.: +34-923-294532; Fax: +34-923-294611
}

check for

updates

Citation: Flores-Félix, J.D.; Velázquez, E.; Martínez-Molina,

E.; gonzález-Andrés, F.; Squartini, A.; Rivas, R. Connecting the Lab and the Field: Genome Analysis of Phyllobacterium and Rhizobium Strains and Field Performance on Two Vegetable Crops. Agronomy 2021, 11, 1124. https://doi.org/10.3390/ agronomy11061124

Academic Editor: John P. Thompson

Received: 22 April 2021

Accepted: 29 May 2021

Published: 31 May 2021

Publisher's Note: MDPI stays neutral with regard to jurisdictional claims in published maps and institutional affiliations.

Copyright: (c) 2021 by the authors. Licensee MDPI, Basel, Switzerland. This article is an open access article distributed under the terms and conditions of the Creative Commons Attribution (CC BY) license (https:// creativecommons.org/licenses/by/ $4.0 /)$.

Abstract: The legume nodules are a rich source not only of rhizobia but also of endophytic bacteria exhibiting plant growth-promoting mechanisms with potential as plant biostimulants. In this work we analyzed the genomes of Phyllobacterium endophyticum PEPV15 and Rhizobium laguerreae PEPV16 strains, both isolated from Phaseolus vulgaris nodules. In silico analysis showed that the genomes of these two strains contain genes related to $N$-acyl-homoserine lactone (AHL) and cellulose biosynthesis, involved in quorum sensing and biofilm formation, which are essential for plant colonization. Several genes involved in plant growth promotion such as those related to phosphate solubilization, indole acetic acid production, siderophore biosynthesis and nitrogen fixation were also located in both genomes. When strains PEPV15 and PEPV16 were inoculated in lettuce and carrot in field assays, we found that both significantly increased the yield of lettuce shoots and carrot roots by more than $20 \%$ and $10 \%$, respectively. The results of this work confirmed that the genome mining of genes involved in plant colonization and growth promotion is a good strategy for predicting the potential of bacterial strains as crops inoculants, opening new horizons for the selection of bacterial strains with which to design new, effective bacteria-based plant biostimulants.

Keywords: Phyllobacterium; Rhizobium; carrot; lettuce; bacterial endophytes; plant growth promotion; PGPB; genomics; microbial biostimulants; field assays

\section{Introduction}

New perspectives in agriculture include the use of technologies able to reduce its impact on the environment through a maximization of the efficiency in the use of resources. Within these technologies, crop inoculation with plant growth-promoting bacteria (PGPB) is one of the most attractive for sustainable agriculture [1,2]. In the last decade, several studies on the diversity of PGPB [3] and their potential to colonize plant roots [4] and to exhibit in vitro plant growth promotion mechanisms have been published [5]. These bacteria can inhabit the plant rhizosphere or the inner tissues of plants [6], plant endophytes being the most efficient inoculants [7]. For this reason, in the past year, several research studies have evaluated ways of increasing plant growth by using bacterial endophytes isolated from non-legume plants [8,9] and from legume nodules [10-18]. These nodules contain the 
rhizobia responsible for their formation and for symbiotic nitrogen fixation as well as other bacterial endophytes with different plant growth promotion mechanisms [19-22].

Plant growth promotion mechanisms are related to the presence of several genes in the bacterial genomes whose analysis allows us to understand the adaptation of bacteria to plants $[23,24]$, but few studies analyzing the genomes of PGPB endophytes inhabiting legume nodules have been carried out to date $[12,17,18]$. genome analysis can help to improve the selection process of PGPB and to commonly focus on the search for genes involved in metabolic pathways related to plant growth promotion $[25,26]$. However, the presence of these genes in the genome of a strain is not enough to ensure its effective performance on plants, and thus in silico genome mining should be accompanied by the analysis of plant effects, with field trials being the only way to verify the real potential of strains as crop biostimulants. Although this was the approach in some recent research on inoculating endophytic bacteria on non-legumes [27,28] and rhizobia on common bean [29], there are no studies relating in silico analysis and field performance for endophytic bacteria inhabiting legume nodules.

Therefore, the aims of this study were: (i) to perform a comparative in silico analysis of the whole genomes of two strains isolated from common bean nodules, Phyllobacterium endophyticum PEPV15 and Rhizobium laguerreae PEPV16 [30,31], which have similar in vitro plant growth patterns and are able to colonize lettuce and carrot roots and to promote the growth of the edible parts of these plants in pre-field studies carried out in microcosm conditions [32-35], and (ii) to carry out preliminary assays in commercial fields in order to evaluate the potential of these two strains as biostimulants of lettuce and carrot plants, two vegetables widely consumed worldwide in which the effects of the inoculation of rhizobia or legume nodule endophytic bacteria have not been studied to date.

\section{Materials and Methods}

\subsection{Genome Analysis}

To obtain genomic DNA, the strains P. endophyticum PEPV15 and R. laguerreae PEPV16 were grown on TY plates (Triptone Yeast Agar) [36] during $24 \mathrm{~h}$ at $28^{\circ} \mathrm{C}$. genomic DNA was obtained using the ZR Fungal/Bacterial DNA MiniPrep (Zymo Research, Irvine, CA, USA) following the manufacturer's protocol. Sequencing, upon preparation of pairedend libraries, was performed on an Illumina MiSeq sequencing platform $(2 \times 250 \mathrm{bp})$. Sequencing data were assembled using Velvet 1.2.10 [37]. The draft genome sequences of strains PEPV15 and PEPV16 were deposited in DDBJ/EMBL/GenBank under the BioProjects PRJNA562136 (accession number VSZT00000000) and PRJNA224116 (accession number VSZV00000000), respectively. Annotation was done using RAST 2.0 (Rapid Annotation using Subsystem Technology) [38,39] and the NCBI Prokaryotic genome Annotation Pipeline (PGAP) (https:/ / www.ncbi.nlm.nih.gov/genome/annotation_prok/ (accessed on 15 March 2021)) [40,41]. KofamKOALA tool was used to annotate the genomes based on the KEGG database [42]. The circular genome map of the studied strains was generated using the CGView server (http:/ / cgview.ca / (accessed on 15 March 2021)) [43,44].

\subsection{Quorum Sensing Assays}

For the evaluation of the production of quorum sensing signals, the strains PEPV15 and PEPV16 were grown in $20 \mathrm{~mL}$ of YMB medium [45] during $48 \mathrm{~h}$. Then $2 \mathrm{~mL}$ was transferred to $18 \mathrm{~mL}$ of $\mathrm{YMB}$ medium and was incubated during $24 \mathrm{~h}$ at $28^{\circ} \mathrm{C}$. The cultures were centrifuged $4 \mathrm{~min}$ at $4500 \times g$, and the supernatants were filtered with a $0.22 \mu \mathrm{m}$ pore filter. The strain Agrobacterium tumefaciens NTL4 (pZRL4) was employed as reporter of AHL (acylated homoserine lactone) quorum sensing molecules. This strain was inoculated in $20 \mathrm{~mL}$ of liquid $\mathrm{AB}$ medium [46] supplemented with $30 \mu \mathrm{g} / \mathrm{mL}$ gentamycin and was incubated for $24 \mathrm{~h}$ at $28{ }^{\circ} \mathrm{C}$. Then, $10 \mathrm{~mL}$ of this culture was mixed with $\mathrm{AB}$ medium with agarose $(1 \% w / v)$ at $43{ }^{\circ} \mathrm{C}$ and $150 \mu \mathrm{L}$ of X-gal (5-bromo-4-chloro-3-indolyl-beta-Dgalactopyranoside) stock solution for a final concentration $60 \mu \mathrm{g} / \mathrm{mL}$. Aliquots of $200 \mu \mathrm{L}$ of this suspension were dispensed in each well of a 96-well microtiter plate. Upon medium 
solidification, $10 \mu \mathrm{L}$ of a solution containing $10 \mathrm{ng} / \mu \mathrm{L}$ of $\mathrm{OHL}$ (N-3-octanoyl homoserine lactone, Sigma Aldrich Co., St. Luis, MO, USA), filtered supernatants, and their serial dilutions was added. OHL was chosen as AHL positive control. After $24 \mathrm{~h}$ of incubation the digital image was acquired by a HP Scanjet 8200 flatbed scanner.

\subsection{Field Experiments}

The field experiment was conducted in Spain for two vegetable crops in one environment each. The soil characteristics of the experimental field are shown in Table 1 and the climatic conditions during the experiment in Table 2.

Table 1. Edaphic conditions corresponding to the fields from this study.

\begin{tabular}{|c|c|c|c|}
\hline \multicolumn{2}{|c|}{ Location } & Remondo & Ciudad Rodrigo \\
\hline \multicolumn{2}{|c|}{ Crop } & Carrot & Lettuce \\
\hline \multicolumn{2}{|c|}{$\begin{array}{c}\text { Latitude } \\
\text { Longitude }\end{array}$} & $\begin{array}{l}41^{\circ} 20^{\prime} 00.9^{\prime \prime} \mathrm{N} \\
4^{\circ} 29^{\prime} 30.7^{\prime \prime} \mathrm{W}\end{array}$ & $\begin{array}{c}40^{\circ} 35^{\prime} 02.6^{\prime \prime} \mathrm{N} \\
6^{\circ} 31^{\prime} 56.1^{\prime \prime} \mathrm{W}\end{array}$ \\
\hline \multirow{3}{*}{ Texture (\%) } & Sand & 93.1 & 30.6 \\
\hline & Silt & 2.3 & 50.3 \\
\hline & Clay & 4.6 & 19.1 \\
\hline pH 1:2 & (soil: water) & 7.0 & 7.6 \\
\hline Electric conductivity & $(\mathrm{dS} / \mathrm{m})$ & 0.15 & 0.25 \\
\hline Organic matter & $(\%)$ & 0.11 & 5.44 \\
\hline Total nitrogen * & $(\%)$ & 0.01 & 0.35 \\
\hline Ratio C/N & & 4.3 & 9.0 \\
\hline Lime & $(\%)$ & 0.29 & 3.64 \\
\hline P-Olsen & $\left(\mathrm{mg} \mathrm{kg}^{-1}\right)$ & 33.0 & 280.0 \\
\hline K & $\left(\mathrm{cmol}(+) \mathrm{kg}^{-1}\right)$ & 0.25 & 1.36 \\
\hline $\mathrm{Ca}$ & $\left(\mathrm{cmol}(+) \mathrm{kg}^{-1}\right)$ & 4.10 & 23.6 \\
\hline Mg & $\left(\mathrm{cmol}(+) \mathrm{kg}^{-1}\right)$ & 1.09 & 5.11 \\
\hline $\mathrm{Na}$ & $\left(\mathrm{cmol}(+) \mathrm{kg}^{-1}\right)$ & 0.69 & 0.13 \\
\hline
\end{tabular}

* Total N: organic + nitric + ammonia nitrogen.

Table 2. Climatic conditions corresponding to the field experiments in the year 2013. The climatic data were recorded at the Segovia and Saelices el Chico (Salamanca) weather stations.

\begin{tabular}{|c|c|c|c|c|c|c|c|}
\hline \multirow{2}{*}{ Location } & \multirow{2}{*}{ Month } & \multicolumn{5}{|c|}{ Temperatures $\left({ }^{\circ} \mathrm{C}\right) *$} & \multirow{2}{*}{ Monthly Rainfall (mm) } \\
\hline & & $\operatorname{Hmax}\left({ }^{\circ} \mathrm{C}\right)$ & Havg $\left({ }^{\circ} \mathrm{C}\right)$ & Tavg $\left({ }^{\circ} \mathrm{C}\right)$ & Lavg $\left({ }^{\circ} \mathrm{C}\right)$ & $\operatorname{Lmin}\left({ }^{\circ} \mathrm{C}\right)$ & \\
\hline \multirow{6}{*}{$\begin{array}{l}\text { Remondo } \\
\text { (Segovia station) } \\
\text { (Carrot crop) }\end{array}$} & May & 23.0 & 16.0 & 10.3 & 5.1 & 0.4 & 69.8 \\
\hline & June & 31.0 & 23.9 & 16.7 & 9.5 & 3.3 & 7.0 \\
\hline & July & 34.6 & 31.3 & 23.6 & 15.9 & 9.8 & 9.2 \\
\hline & August & 35.8 & 30.3 & 22.4 & 14.4 & 8.8 & 0.4 \\
\hline & September & 31.9 & 25.5 & 18.9 & 12.2 & 5.8 & 27.4 \\
\hline & October & 25.4 & 19.6 & 14.4 & 9.2 & 0.7 & 32.4 \\
\hline \multirow{4}{*}{$\begin{array}{c}\text { Ciudad Rodrigo } \\
\text { (Saelices el Chico station) } \\
\text { (Lettuce crop) }\end{array}$} & June & 34.0 & 26.5 & 18.5 & 10.5 & 8.8 & 18.2 \\
\hline & July & 38.5 & 33.3 & 23.9 & 14.5 & 8.7 & 0.6 \\
\hline & August & 38.9 & 32.6 & 23.2 & 13.9 & 8.7 & 0.0 \\
\hline & September & 34.2 & 28.0 & 20.1 & 12.1 & 7.5 & 119 \\
\hline
\end{tabular}

* Hmax: maximum high temperature) $\left({ }^{\circ} \mathrm{C}\right)$; Havg: average high temperature $\left({ }^{\circ} \mathrm{C}\right)$; Tavg: average mean temperature $\left({ }^{\circ} \mathrm{C}\right)$; Lavg: average low temperature $\left({ }^{\circ} \mathrm{C}\right)$; Lmin: minimum low temperature $\left({ }^{\circ} \mathrm{C}\right)$.

The carrot (Daucus carota L.) experiment was conducted in Remondo (Segovia, Spain) $\left(41^{\circ} 20^{\prime} 0.9^{\prime \prime} \mathrm{N} 4^{\circ} 29^{\prime} 30.7^{\prime \prime} \mathrm{W}\right)$. The Segovia province is the largest carrot production region in Spain. The agronomic practices were those commonly used in the carrot integrated production system. In brief, the tillage was minimal and consisted of two crossed passes with harrow before sowing. Fertilization consisted of $51 \mathrm{~kg} \mathrm{~N}, 68 \mathrm{~kg} \mathrm{P}_{2} \mathrm{O}_{5}$, and $170 \mathrm{~kg}$ $\mathrm{K}_{2} \mathrm{O}$ in the form of $850 \mathrm{~kg} \mathrm{ha}^{-1}$ of the complex fertilizer 6-8-20, applied before sowing. The cultivar was "Nandrín", and the seeds were mechanically sowed (16 May 2013) to a 
final density of 510,000 plants ha $^{-1}$ in rows at $30 \mathrm{~cm}$ spacing. When seedlings showed three leaves, each carrot plant belonging to the inoculated treatments received $10 \mathrm{~mL}$ of a bacterial suspension with $1 \times 10^{7} \mathrm{cfu} \mathrm{mL}^{-1}$. The crop was sprinkler irrigated. The soil was mechanically kept free from weeds. In order to prevent fungal diseases and pests, two treatments with sulphur $80 \%$ (water-dispersible granules) were carried out during the growing season, at a dose of $1 \mathrm{~kg}$ per ha.

The lettuce (Lactuca sativa L.) field experiment was conducted in Ciudad Rodrigo (Salamanca, Spain) $\left(40^{\circ} 35^{\prime} 2.6^{\prime \prime} \mathrm{N} 6^{\circ} 31^{\prime} 56.1^{\prime \prime} \mathrm{W}\right)$, a region with a long tradition in seasonal vegetable production. The agronomic practices corresponded to an organic system; in brief, the tillage consisted of two passes with harrow in autumn, plus the seedbed preparation with a power harrow in spring. Fertilization was organic, with a dose of $10 \mathrm{t} \mathrm{ha}^{-1}$ of composted beef manure provided before transplanting. The lettuce cv. was "Romana". Seedlings were produced in a seedbed in individual pots with professional substratum (Pindstrup Plus Orange). Seedlings were grown in a greenhouse until the plants developed three leaves, and were then transplanted to the field (2 June 2013) to a final density of 20,000 plants ha $^{-1}$ in rows separated by $60 \mathrm{~cm}$. Three days after transplanting, each lettuce plant belonging to the inoculated treatments received $10 \mathrm{~mL}$ of a bacterial suspension with $1 \times 10^{7} \mathrm{cfu} \mathrm{mL}^{-1}$. Irrigation was by sprinklers. Weeds were mechanically removed, and $500 \mathrm{~g}$ of chitosan (Poly-D glucosamine) diluted in $300 \mathrm{~L}$ water was sprayed per ha 21 days after transplanting with the purpose of improving plant natural resistance against pathogenic bacteria and fungi. No other phytosanitary treatment was carried out.

For the two crops, the experimental design consisted of a randomized complete block with three blocks. The experimental unit consisted of five rows of 10 plants per row in carrot and five rows of 5 plants per row in lettuce. To avoid microorganisms spreading in the soil, treatments were separated by five rows in carrot and one in lettuce, and blocks were separated by $2 \mathrm{~m}$. For sampling, the 6 central plants of the three central rows in carrot, and the 3 central plants of the three central rows in lettuce were collected. Thus, 18 plants for carrot and 9 plants for lettuce per experimental unit were collected, weighted while fresh, and dried at $70{ }^{\circ} \mathrm{C}$ until constant weight for dry weight measurement and elemental analysis. The analysis of N, P, K, Ca, Fe, and Mg was performed at the Ionomic Service of CEBAS-CSIC (Spain). Univariate analysis of variance with block as a random factor and treatment as a fixed one was performed. The normality of standardized residuals was checked with Kolmogorov-Smirnov's test and the homoscedasticity with Levene's test. Mean values were compared with the Tukey post hoc test. Statistical analysis was conducted with SPSS v.26.

\section{Results}

\subsection{Genome features}

The characteristic of the whole genomes of the strains PEPV15 and PEPV16 are recorded in Table 3. Circular representation of the genome is shown in the Figure 1A,B, and functions classified in different categories of metabolism using RAST annotation service are shown in the Figure 1C,D. A similar distribution in annotated subsystems was observed in both strains (Figure 1C,D) and a similar number of RNA genes harbored each genome (Table 3); however, amino acid and derivative associated genes were more abundant in the genome of the strain PEPV16 than in that of the strain PEPV15 (Figure 1C,D). 
Table 3. Genome characteristics of 1 , Phyllobacterium endophyticum $\mathrm{PEPV}^{\mathrm{T}} 5^{\mathrm{T}} ; 2$, Rhizobium laguerreae PEPV16.

\begin{tabular}{ccc}
\hline Genome Data & $\mathbf{1}$ & $\mathbf{2}$ \\
\hline DDBJ/EMBL/GenBank accession number & VSZT00000000 & VSZV00000000 \\
Sequence size (bp) & $5,505,652$ & $7,182,427$ \\
Number of contigs & 15 & 356 \\
GC content (\%) & 58.30 & 57.20 \\
Shortest contig size & 322 & 252 \\
Longest contig size & $2,119,450$ & 557,230 \\
N50 value & 332,658 & 437,109 \\
L50 value & 5 & 74 \\
Number of coding sequences & 5152 & 7108 \\
Number of RNAs (tRNAs, rRNAs, others RNAs) & $52(45,3,4)$ & $53(44,5,4)$ \\
\hline
\end{tabular}
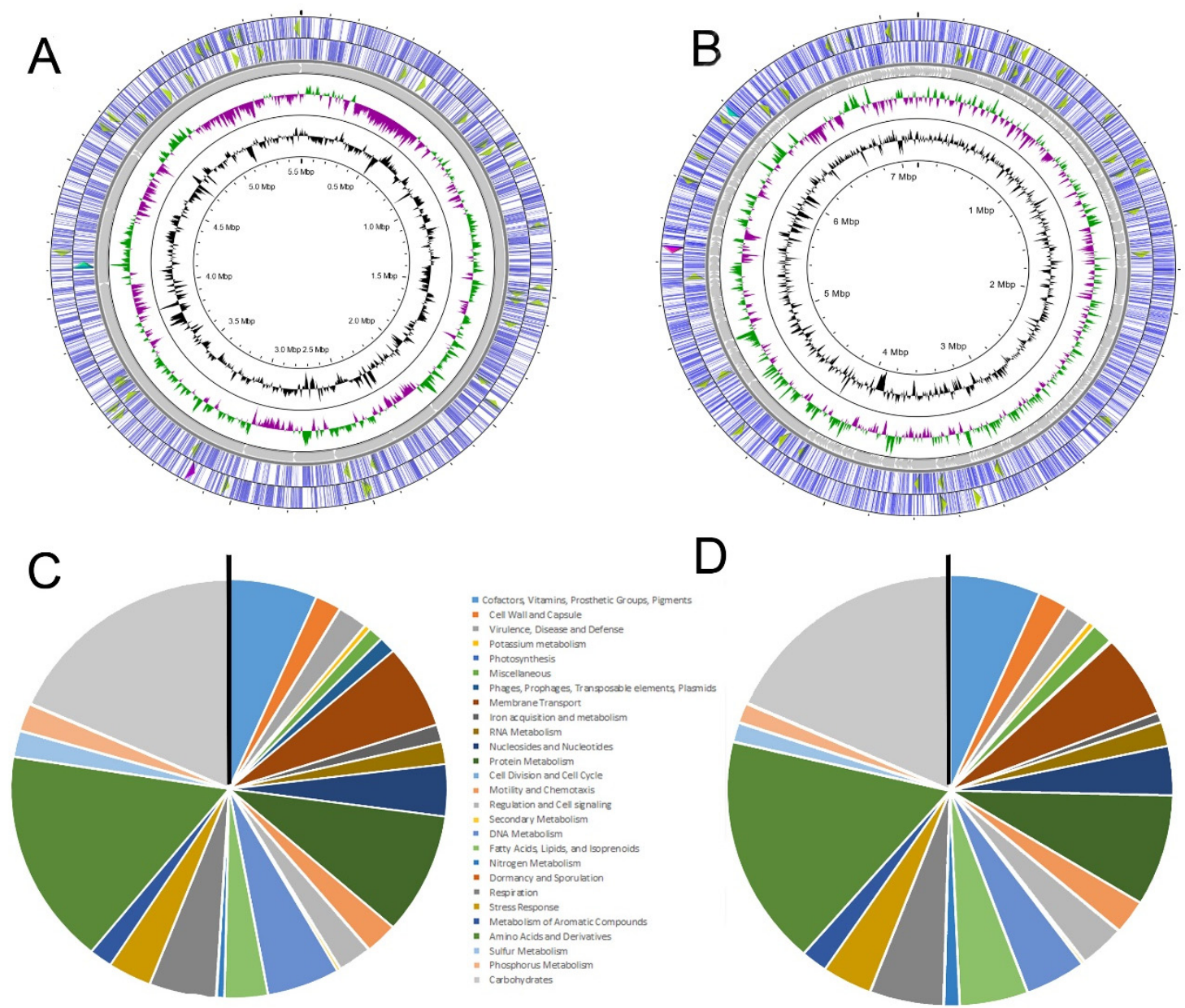

Figure 1. Genome circular representation and subsystems category distribution of annotated genes of the Phyllobacterium endophyticum PEPV15 $^{\mathrm{T}}$ genome $(\mathbf{A}, \mathbf{C})$ and the Rhizobium laguerreae PEPV16 ${ }^{\mathrm{T}}(\mathbf{B}, \mathbf{D})$. (A,B) From the outer to inner circles show coding sequences (CDSs; blue), rRNAs (violet), tmRNAs (turquoise), contigs (light grey), gC content (black), gC skew curves (+ / - ; green/purple). (C,D) Annotation of Phyllobacterium endophyticum PEPV15 ${ }^{\mathrm{T}}$ and Rhizobium laguerreae PEPV16 genomes via the RAST server, respectively. Subsystems are placed following the order of the legend, starting at the position of the black bar, from right to left. 


\subsection{Analysis of genes Involved in Quorum Sensing and Plant Colonization}

The colonization of plant roots is essential for a beneficial plant-bacteria association with significant agronomic effects [29]. Together with bacterial cellulose, quorum sensing compounds are involved in biofilm formation and plant colonization [47,48]. The production of cellulose has already been shown for strains PEPV15 and PEPV16 [32,33], and as expected, their genomes contain the $b c s A$ and $b c s B$ genes that encode a UDP-forming cellulose synthase catalytic subunit and a cellulose biosynthesis cyclic di-GMP-binding regulatory protein, respectively, as occurs in other bacteria [47]. These two genes are enough to produce cellulose in vitro $[47,49]$, but both genomes contain a third gene encoding an endonuclease, which has also been found in the genomes of other Rhizobium strains [50]. This enzyme (CelC2) has cellulase activity on CMC plates, is encoded by the celC gene in Rhizobium strains, and is involved in cellulose biosynthesis and biofilm formation [51].

Concerning to the quorum sensing compounds, in the case of rhizobia, they are related to the $N$-acyl-homoserine lactone groups (AHLs) [52,53]. In this study, we detected the production of AHL in both strains after dilutions 1:125 and 1:3126 for the strains PEPV15 and PEPV16, respectively. In agreement with these results, we found in the genome of the strain PEPV16 a gene encoding a N-acyl-L-homoserine lactone (AHL) synthase and in that of strain PEPV15 a gene encoding a GNAT family $\mathrm{N}$-acetyltransferase involved in AHL biosynthesis [54].

Other genes related to plant colonization are those involved in motility, chemotaxis, and exopolysaccharide biosynthesis, which mediate biofilm formation and plant surface attachment [26]. The genes involved in plant colonization that are found in the genomes of strains PEPV15 and PEPV16 are recorded in Table S1.

\subsection{Analysis of Genes Involved in Plant growth Promotion}

Bacteria able to colonize plant roots can promote plant growth through several widely studied mechanisms, although some of them could remain unknown [5]. Several genes directly or indirectly related to plant growth promotion mechanisms can be mined in bacterial genomes [25] because good PGPB strains accumulate several of these genes [26]. The strains PEPV15 and PEPV16 showed similar patterns of in vitro plant growth promotion mechanisms that include phosphate solubilization, IAA production, and siderophore biosynthesis [32,33]; therefore, we searched the genes involved in these mechanisms in their genomes (Table S1).

An important skill in a PGPB is phosphate solubilization because phosphorous is, after nitrogen, the second limiting element in terrestrial ecosystems, and only a low percentage of this element present in soils is available for the plants [55]. Phosphorous can be released from soil organic compounds by several types of phosphatases and from inorganic ones through mineralization by organic acids originated during the bacterial growth, with the enzyme glucose dehydrogenase and the co-factor pyrroloquinoline quinone being involved in this process [56]. Both strains PEPV15 and PEPV16 harbored in their genomes different types of phosphatases that can carry out the solubilization of phosphate from organic compounds. In addition, the strain PEPV15 contains the $p q q B, p q q C, p q q D$, and $p q q E$ genes, which are required for biosynthesis of pyrroloquinoline quinone and are markers for phosphate mineralization [25].

The production of the phytohormone indole acetic acid (IAA) is one of the most studied plant growth-promoting mechanisms in bacteria [57], with the indole-3-acetamide, the indole-3-pyruvic acid, and the indole-3-acetonitrile/indole-3-acetaldoxime being the most studied pathways involved in the production of IAA in bacteria. Bruto et al. [25] included in their research the indole-3-pyruvate decarboxylase/phenylpyruvate decarboxylase genes (ipdC and $p p d C$ ) involved in the IAA synthesis indole-3-pyruvate pathway, but these genes were not found in the genomes of strains PEPV15 and PEPV16. Other genes involved in IAA production via the indole-3-acetamide (IAM) pathway, such as iaaM and iaaH [58], and the enzyme acetaldoxime dehydratase involved in the conversion of IAN into IAA [59], were not found in the genomes of the strains PEPV15 and PEPV16. However, bacteria 
can produce IAA through some alternative ways or by using other enzymes that have not been well studied [58]. It is interesting to note that in the PEPV15 genome, a nitrilase was found, and two subunits of a nitrile hydratase $(n t h A B)$ were found in both genomes. These enzymes participate in the last steps of the formation of IAA through the indole-3acetonitrile/indole-3-acetaldoxime pathway from indole-3-acetonitrile (IAN) [59].

Siderophore production is considered within both direct and indirect plant growth promotion mechanisms [5]. The genome of strain PEPV15 contains an unnamed gene encoding a siderophore biosynthesis protein (accession in genProt PSH59744.1), while strain PEPV16 contains a gene encoding an acetyltransferase that is highly similar (higher than $92 \%$ similarity) to the $v b s A$ gene that encodes a protein required for biosynthesis of vicibactin, a siderophore produced by Rhizobium [60].

These findings confirmed that in silico genome analyses are a good tool for detecting potential plant growth-promoting bacteria since the strains whose genome contains several genes involved in plant colonization and growth promotion mechanisms also display these mechanisms in vitro, and moreover, they showed good behavior in plant experiments carried out in microcosm conditions $[26,32,33]$. However, the incorporation of these strains in commercial inoculants requires conducting field experiments that have rarely been performed to date after the genome analysis of endophytic PGPB strains [27-29].

\subsection{Field Trials}

We performed field trials inoculating lettuces and carrots with strains PEPV15 and PEPV16 in commercial fields because these strains were able to colonize the roots of these two vegetables and to promote their plant growth in microcosm conditions [32,34,35]. However, only one environment per crop was analyzed, and the obtained results should be considered preliminary since this work was conducted in professional farmers' fields; nonetheless, it provides accurate information on the real effect of the MPB (microbial plant biofertilizer) in commercial situations.

The results obtained in the carrot field experiment showed that both fresh and dry root biomass significantly increased after inoculation with both strains of PEPV15 and PEPV16 with respect to the uninoculated plants (Table 4). The yield $\left(\mathrm{t} \mathrm{ha}^{-1}\right)$ increased $22 \%$ with PEPV16 and 28\% with PEPV15. No significant differences were found in the N and Fe concentration in the aerial biomass among treatments. Conversely, the $\mathrm{P}, \mathrm{Ca}$, and $\mathrm{Mg}$ concentration significantly increased as a result of inoculation, regardless of the strain. The concentration of Mg was significantly higher when strain PEPV16 was inoculated compared with the strain PEPV15 and with the uninoculated control (Table 5).

Table 4. Mean values and standard errors corresponding to the roots and shoots biomasses produced by carrot and lettuce crops, respectively, after the inoculation with the PEPV15 and PEPV16 strains and in the uninoculated controls in the field experiment. The values followed by the same letter did not significantly differ in the Tukey test. ANOVA was performed with blocks as a random factor and the treatment as a fixed factor ( $p$-value: $\left.{ }^{* *} p \leq 0.001\right)$. Data refer to a single plant, and yield was calculated for an expected final density of 510,000 plants ha ${ }^{-1}$.

\begin{tabular}{|c|c|c|c|c|c|}
\hline \multirow{2}{*}{$\begin{array}{l}\text { Crop/Treatment } \\
\text { Carrot (Roots) }\end{array}$} & \multicolumn{4}{|c|}{ Biomass per Plant (g) } & Expected Yield (t ha $\left.{ }^{-1}\right)$ \\
\hline & & & & & \\
\hline Uninoculated control & $61.82( \pm 2.63)$ & $\mathrm{b}$ & $6.40( \pm 0.25)$ & $\mathrm{b}$ & 31.5 \\
\hline PEPV16 & $75.03( \pm 3.39)$ & a & $7.57( \pm 0.32)$ & $\mathrm{a}$ & 38.3 \\
\hline PEPV15 & $79.02( \pm 2.79)$ & a & $8.01( \pm 0.24)$ & a & 40.3 \\
\hline Mean square & \multicolumn{2}{|l|}{4376.998} & \multicolumn{2}{|c|}{37.335} & \\
\hline$F$-value and significance & 9.288 & $* * *$ & 9.280 & $* * *$ & \\
\hline \multicolumn{6}{|l|}{ Lettuce (shoots) } \\
\hline Uninoculated control & $1289( \pm 42)$ & $\mathrm{b}$ & $65.4( \pm 2.1)$ & $\mathrm{b}$ & 25.8 \\
\hline PEPV15 & $1432( \pm 44)$ & a & $74.8( \pm 2.6)$ & $\mathrm{a}$ & 28.6 \\
\hline PEPV16 & $1507( \pm 25)$ & $\mathrm{a}$ & $82.8( \pm 2.3)$ & $\mathrm{a}$ & 30.1 \\
\hline Mean square & $331,459.370$ & & & & \\
\hline$F$-value and significance & 8.496 & $* * *$ & 13.695 & $* * *$ & \\
\hline
\end{tabular}




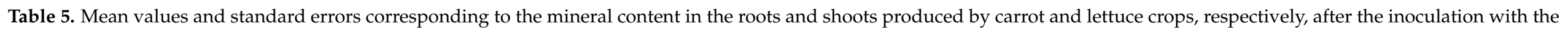

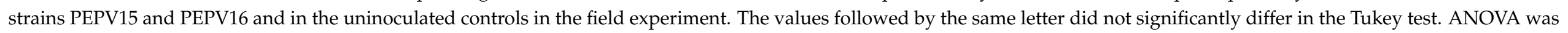
performed with blocks as a random factor and the treatment as a fixed factor ( $p$-value: ${ }^{* *} p \leq 0.001 ;{ }^{* *} 0.001<p \leq 0.01{ }^{*} 0.01<p \leq 0.05$ : ns, not significant).

\begin{tabular}{|c|c|c|c|c|c|c|c|c|c|c|c|c|}
\hline & \multicolumn{2}{|c|}{$N(g / 100 g)$} & \multicolumn{2}{|c|}{$P(\mathrm{mg} / \mathrm{kg})$} & \multicolumn{2}{|c|}{$\mathrm{K}(\mathrm{mg} / \mathrm{kg})$} & \multicolumn{2}{|c|}{$\mathrm{Mg}(\mathrm{mg} / \mathrm{kg})$} & \multicolumn{2}{|c|}{$\mathrm{Ca}(\mathrm{mg} / \mathrm{kg})$} & \multicolumn{2}{|c|}{$\mathrm{Fe}(\mathrm{mg} / \mathrm{kg})$} \\
\hline Uninoculated control & $1.04( \pm 0.044)$ & a & $2127( \pm 91)$ & $\mathrm{b}$ & $24,547( \pm 923)$ & $\mathrm{b}$ & $1058( \pm 46)$ & c & $2742( \pm 154)$ & $\mathrm{b}$ & $116( \pm 14)$ & a \\
\hline PEPV15 & $1.10( \pm 0.008)$ & a & $2529( \pm 27)$ & a & $30,886( \pm 645)$ & $\mathrm{a}$ & $1244( \pm 17)$ & $\mathrm{b}$ & $3325( \pm 42)$ & a & $78( \pm 5)$ & $\mathrm{a}$ \\
\hline Mean Square & \multicolumn{2}{|l|}{0.007} & \multicolumn{2}{|c|}{$509,536.343$} & \multicolumn{2}{|c|}{$40,234,943.659$} & \multicolumn{2}{|c|}{$127,293.063$} & \multicolumn{2}{|c|}{$401,076.976$} & \multicolumn{2}{|c|}{1967.711} \\
\hline$F$ value and significance & 0.840 & ns & 17.957 & $* * *$ & 13.705 & $* *$ & 19.920 & $* * *$ & 7.761 & $*$ & 4.128 & ns \\
\hline \multicolumn{13}{|l|}{ Lettuce (shoots) } \\
\hline Uninoculated control & $3.39( \pm 0.030)$ & a & $3842( \pm 149)$ & a & $50,659( \pm 2025)$ & $\mathrm{a}$ & $2988( \pm 94)$ & $a b$ & $9604( \pm 397)$ & $\mathrm{b}$ & $642( \pm 67)$ & a \\
\hline PEPV15 & $3.43( \pm 0.059)$ & a & $4238( \pm 168)$ & a & $52,011( \pm 2210)$ & a & $2877( \pm 49)$ & $\mathrm{b}$ & $9949( \pm 123)$ & $\mathrm{b}$ & $766( \pm 106)$ & a \\
\hline PEPV16 & $3.62( \pm 0.083)$ & a & $4243( \pm 113)$ & $\mathrm{a}$ & $54,865( \pm 1597)$ & $\mathrm{a}$ & $3385( \pm 140)$ & $\mathrm{a}$ & $12,576( \pm 446)$ & $\mathrm{a}$ & $1034( \pm 179)$ & $\mathrm{a}$ \\
\hline Mean Square & \multicolumn{2}{|l|}{0.058} & \multicolumn{2}{|c|}{$212,160.780$} & \multicolumn{2}{|c|}{$18,436,322.965$} & \multicolumn{2}{|c|}{$285,011.620$} & \multicolumn{2}{|c|}{$10,572,050.235$} & \multicolumn{2}{|c|}{$160,557.838$} \\
\hline$F$ value and significance & 3.862 & ns & 2.515 & ns & 1.199 & ns & 6.883 & $* *$ & 21.334 & $* * *$ & 2.517 & ns \\
\hline
\end{tabular}


The results obtained in the lettuce field experiment showed a significant increase of fresh and dry aerial biomass inoculating with both strains PEPV15 and PEPV16, compared with the uninoculated controls (Table 4$)$. The fresh yield $\left(\mathrm{t} \mathrm{ha}^{-1}\right)$ increased by $11 \%$ and $16 \%$ in plants inoculated with strains PEPV15 and PEPV16, respectively, compared with the uninoculated controls (Table 4). No significant differences were found in the content of $\mathrm{N}, \mathrm{P}, \mathrm{K}, \mathrm{Mg}$, or Fe among treatments, whilst the contents of Ca were significantly higher in the plants inoculated with the strain PEPV16 compared with the rest of the treatments (Table 5).

To date, no field trials assays have been carried out in lettuce or carrots inoculating rhizobial strains or legume nodule endophytes, and only a few field trials assays have been performed in lettuce after inoculation with Bacillus strains, which showed increases ranging from 13\% to 20\% [61-63] and with Pseudomonas strains, which increased plant yield by $30 \%$ [64]. Therefore, this is the first field trial conducted with these two vegetables that demonstrated the biostimulant effect of strains of two genera belonging to the order Rhizobiales-namely, Rhizobium and Phyllobacterium, inhabiting legume nodules. Although the increases in the production were lower after the inoculation of these strains than in the case of Pseudomonas inoculation, rhizobial strains have particular advantages as biostimulants since they have been used for decades for legume inoculation without observing problems either for the environment or for plant, animal, or human health, which is essential for the inoculation of vegetables that can be consumed fresh, which occurs in the case of carrots and lettuce.

\section{Conclusions}

In the present work, a good agronomic performance upon the inoculation of P. endophyticum PEPV15 and R. laguerreae PEPV16 on lettuce and carrots was demonstrated, which can be explained by the presence of an assortment of genes related to root colonization ability and several PGP activities in their bacterial genomes. Thus, the genome mining of these genes qualifies as a sound strategy for predicting the potential of bacterial strains as crop inoculants and this work opens new horizons for the selection of bacterial strains with which to design new effective bacteria-based plant biostimulants.

Supplementary Materials: The following are available online at https:/ / www.mdpi.com/article / 10.3390/agronomy11061124/s1, Table S1: genes involved in plant colonization and plant growth promotion found in the genomes of Phyllobacterium endophyticum PEPV15 and Rhizobium laguerreae PEPV16.

Author Contributions: Conceptualization, R.R., E.V., and A.S.; methodology, J.D.F.-F., R.R., E.V., E.M.-M., A.S., and F.G.-A.; validation, E.V., E.M.-M., A.S., and F.G.-A.; formal analysis, E.V., E.M.-M., A.S., and F.G.-A.; investigation, J.D.F.-F.; data curation, R.R., E.V., and F.G.-A.; writing-original draft preparation, J.D.F.-F.; writing-review and editing, R.R., E.V., E.M.-M., A.S., and F.G.-A.; supervision, E.M.-M.; project administration, R.R.; funding acquisition, R.R. All authors have read and agreed to the published version of the manuscript.

Funding: This work was supported by JCyL (Junta de Castilla y León, Spanish Regional government) grant SA183A11-2 to R.R. J.D.F.-F are granted with a FEMS grant FEMS-RG-2016-0213.

Data Availability Statement: Genome data sequences are available in the genBank under the following accessions: PEPV15 (Bioproject: PRJNA562136; Assembly: ASM818021v1; Accession number: VSZT01000000) and PEPV16 (Bioproject: PRJNA562145; Assembly: ASM891945v1; Accession number: VSZV01000000).

Acknowledgments: J.D.F.-F. is currently a recipient of a postdoctoral Marie Skłodowska-Curie fellowship, No. 101003373. The authors also thank the Excellence Unit of the Spanish-Portuguese Institute for Agricultural Research (CIALE) (CLU-2018-04) for the provision of research facilities.

Conflicts of Interest: The authors declare no conflict of interest. 


\section{References}

1. Gouda, S.; Kerry, R.G.; Das, g.; Paramithiotis, S.; Shin, H.S.; Patra, J.K. Revitalization of plant growth promoting rhizobacteria for sustainable development in agriculture. Microbiol. Res. 2018, 206, 131-140. [CrossRef] [PubMed]

2. Mustafa, S.; Kabir, S.; Shabbir, U.; Batool, R. Plant growth promoting rhizobacteria in sustainable agriculture: From theoretical to pragmatic approach. Symbiosis 2019, 78, 115-123. [CrossRef]

3. Compant, S.; Samad, A.; Faist, H.; Sessitsch, A. A review on the plant microbiome: Ecology, functions, and emerging trends in microbial application. J. Adv. Res. 2019, 19, 29-37. [CrossRef]

4. Kandel, S.L.; Joubert, P.M.; Doty, S.L. Bacterial endophyte colonization and distribution within plants. Microorganisms 2017, 5, 77. [CrossRef] [PubMed]

5. Olanrewaju, O.S.; glick, B.R.; Babalola, O.O. Mechanisms of action of plant growth promoting bacteria. World J. Microbiol. Biotechnol. 2017, 33, 197. [CrossRef]

6. Afzal, I.; Shinwari, Z.K.; Sikandar, S.; Shahzad, S. Plant beneficial endophytic bacteria: Mechanisms, diversity, host range and genetic determinants. Microbiol. Res. 2019, 221, 36-49. [CrossRef]

7. Omomowo, O.I.; Babalola, O.O. Bacterial and Fungal Endophytes: Tiny giants with Immense Beneficial Potential for Plant growth and Sustainable Agricultural Productivity. Microorganisms 2019, 7, 481. [CrossRef]

8. ALKahtani, M.D.F.; Fouda, A.; Attia, K.A.; Al-Otaibi, F.; Eid, A.M.; Ewais, E.D.; Hijri, M.; St-Arnaud, M.; Hassan, S.D.; Khan, N.; et al. Isolation and Characterization of plant growth promoting endophytic bacteria from desert plants and their application as bioinoculants for sustainable agriculture. Agronomy 2020, 10, 1325. [CrossRef]

9. Krishnamoorthy, A.; Agarwal, T.; Kotamreddy, J.N.R.; Bhattacharya, R.; Mitra, A.; Maiti, T.K.; Maiti, M.K. Impact of seedtransmitted endophytic bacteria on intra- and inter-cultivar plant growth promotion modulated by certain sets of metabolites in rice crop. Microbiol. Res. 2020, 241, 126582. [CrossRef]

10. Aeron, A.; Dubey, R.C.; Maheshwari, D.K. Characterization of a plant-growth-promoting non-nodulating endophytic bacterium (Stenotrophomonas maltophilia) from the root nodules of Mucuna utilis var. capitata L. (Safed Kaunch). Can. J. Microbiol. 2020, 66, 670-677. [CrossRef] [PubMed]

11. Aeron, A.; Maheshwari, D.K.; Meena, V.S. Endophytic bacteria promote growth of the medicinal legume Clitoria ternatea L. by chemotactic activity. Arch. Microbiol. 2020, 202, 1049-1058. [CrossRef]

12. Dahmani, M.A.; Desrut, A.; Moumen, B.; Verdon, J.; Mermouri, L.; Kacem, M.; Coutos-Thévenot, P.; Kaid-Harche, M.; Bergès, T.; Vriet, C. Unearthing the plant growth-promoting traits of Bacillus megaterium RmBm31, an endophytic bacterium isolated from root nodules of Retama monosperma. Front. Plant Sci. 2020, 11, 124. [CrossRef]

13. Deng, Z.S.; Kong, Z.Y.; Zhang, B.C.; Zhao, L.F. Insights into non-symbiotic plant growth promotion bacteria associated with nodules of Sphaerophysa salsula growing in northwestern China. Arch. Microbiol. 2020, 202, 399-409. [CrossRef]

14. Soares, R.; Trejo, J.; Lorite, M.J.; Figueira, E.; Sanjuán, J.; Videira, E.; Castro, I. Diversity, phylogeny and plant growth promotion traits of nodule associated bacteria isolated from Lotus parviflorus. Microorganisms 2020, 8, 499. [CrossRef] [PubMed]

15. Tapia-García, E.Y.; Hernández-Trejo, V.; guevara-Luna, J.; Rojas-Rojas, F.U.; Arroyo-Herrera, I.; Meza-Radilla, g.; VásquezMurrieta, M.S.; Estrada-de Los Santos, P. Plant growth-promoting bacteria isolated from wild legume nodules and nodules of Phaseolus vulgaris L. trap plants in central and southern Mexico. Microbiol. Res. 2020, 239, 126522. [CrossRef]

16. Tokgöz, S.; Lakshman, D.K.; ghozlan, M.H.; Pinar, H.; Roberts, D.P.; Mitra, A. Soybean Nodule-Associated Non-Rhizobial Bacteria Inhibit Plant Pathogens and Induce growth Promotion in Tomato. Plants 2020, 9, 1494. [CrossRef] [PubMed]

17. Ali, M.A.; Lou, Y.; Hafeez, R.; Li, X.; Hossain, A.; Xie, T.; Lin, L.; Li, B.; Yin, Y.; Yan, J.; et al. Functional analysis and genome mining reveal high potential of biocontrol and plant growth promotion in nodule-inhabiting bacteria within Paenibacillus polymyxa Complex. Front. Microbiol. 2021, 11, 618601. [CrossRef]

18. Noori, F.; Etesami, H.; Noori, S.; Forouzan, E.; Salehi Jouzani, g.; Malboobi, M.A. Whole genome sequence of Pantoea agglomerans ANP8, a salinity and drought stress-resistant bacterium isolated from alfalfa (Medicago sativa L.) root nodules. Biotechnol. Rep. 2021, 29, e00600. [CrossRef]

19. Velázquez, E.; Carro, L.; Flores-Félix, J.D.; Martínez-Hidalgo, P.; Menéndez, E.; Ramírez-Bahena, M.H.; Mulas, R.; González-Andrés, F.; Martínez-Molina, E.; Peix, A. The Legume Nodule Microbiome: A Source of Plant growth-Promoting Bacteria. In Probiotics and Plant Health; Kumar, V., Kumar, M., Sharma, S., Prasad, R., Eds.; Springer: Singapore, 2017; pp. 41-70.

20. Cardoso, P.; Alves, A.; Silveira, P.; Sá, C.; Fidalgo, C.; Freitas, R.; Figueira, E. Bacteria from nodules of wild legume species: Phylogenetic diversity, plant growth promotion abilities and osmotolerance. Sci. Total Environ. 2018, 645, 1094-1102. [CrossRef]

21. Brígido, C.; Menéndez, E.; Paço, A.; glick, B.R.; Belo, A.; Félix, M.R.; Oliveira, S.; Carvalho, M. Mediterranean native leguminous plants: A reservoir of endophytic bacteria with potential to enhance chickpea growth under stress conditions. Microorganisms 2019, 7, 392. [CrossRef] [PubMed]

22. Ríos-Ruiz, W.F.; Valdez-Nuñez, R.A.; Bedmar, E.J.; Castellano-Hinojosa, A. Utilization of Endophytic Bacteria Isolated from Legume Root Nodules for Plant growth Promotion. In Field Crops: Sustainable Management by PGPR; Maheshwari, D., Dheeman, S., Eds.; Springer: Cham, Switzerland, 2019; Volume 23, pp. 145-176.

23. Paterson, J.; Jahanshah, g.; Li, Y.; Wang, Q.; Mehnaz, S.; gross, H. The contribution of genome mining strategies to the understanding of active principles of PGPR strains. FEMS Microbiol. Ecol. 2017, 93, 1-31. [CrossRef] [PubMed]

24. Levy, A.; Salas gonzalez, I.; Mittelviefhaus, M.; Clingenpeel, S.; Herrera Paredes, S.; Miao, J.; Wang, K.; Devescovi, g.; Stillman, K.; Monteiro, F.; et al. genomic features of bacterial adaptation to plants. Nat. Genet. 2018, 50, 138-150. [CrossRef] [PubMed] 
25. Bruto, M.; Prigent-Combaret, C.; Muller, D.; Moënne-Loccoz, Y. Analysis of genes contributing to plant-beneficial functions in plant growth-promoting rhizobacteria and related Proteobacteria. Sci. Rep. 2015, 4, 6261. [CrossRef] [PubMed]

26. Nascimento, F.X.; Hernandez, A.G.; glick, B.R.; Rossi, M.J. The extreme plant-growth-promoting properties of Pantoea phytobeneficialis MSR2 revealed by functional and genomic analysis. Environ. Microbiol. 2020, 22, 1341-1355. [CrossRef]

27. Jiménez-Gómez, A.; Saati-Santamaría, Z.; Kostovcik, M.; Rivas, R.; Velázquez, E.; Mateos, P.F.; Menéndez, E.; garcía-Fraile, P. Selection of the Root Endophyte Pseudomonas brassicacearum CDVBN10 as Plant growth Promoter for Brassica napus L. Crops. Agronomy 2020, 10, 1788. [CrossRef]

28. Flores, A.; Diaz-Zamora, J.T.; Orozco-Mosqueda, M.C.; Chávez, A.; de los Santos-Villalobos, S.; Valencia-Cantero, E.; Santoyo, g. Bridging genomics and field research: Draft genome sequence of Bacillus thuringiensis CR71, an endophytic bacterium that promotes plant growth and fruit yield in Cucumis sativus L. 3 Biotech 2020, 10, 220. [CrossRef]

29. Pastor-Bueis, R.; Sánchez-Cañizares, C.; James, E.K.; gonzález-Andrés, F. Formulation of a highly effective inoculant for common bean based on an autochthonous elite strain of Rhizobium leguminosarum bv. phaseoli, and genomic-based insights into its agronomic performance. Front. Microbiol. 2019, 10, 2724. [CrossRef]

30. Flores-Félix, J.D.; Carro, L.; Velázquez, E.; Valverde, Á.; Cerda-Castillo, E.; garcía-Fraile, P.; Rivas, R. Phyllobacterium endophyticum sp. nov., isolated from nodules of Phaseolus vulgaris. Int. J. Syst. Evol. Microbiol. 2013, 63, 821-826. [CrossRef]

31. Flores-Félix, J.D.; Sánchez-Juanes, F.; garcía-Fraile, P.; Valverde, A.; Mateos, P.F.; gónzalez-Buitrago, J.M.; Velázquez, E.; Rivas, R. Phaseolus vulgaris is nodulated by the symbiovar viciae of several genospecies of Rhizobium laguerreae complex in a Spanish region where Lens culinaris is the traditionally cultivated legume. Syst. Appl. Microbiol. 2019, 42, 240-247. [CrossRef]

32. Flores-Félix, J.D.; Menéndez, E.; Rivera, L.P.; Marcos-García, M.; Martínez-Hidalgo, P.; Mateos, P.F.; Martínez-Molina, E.; Velázquez, E.; garcía-Fraile, P.; Rivas, R. Use of Rhizobium leguminosarum as a potential biofertilizer for Lactuca sativa and Daucus carota crops. J. Plant Nutr. Soil Sci. 2013, 176, 876-882. [CrossRef]

33. Flores-Félix, J.D.; Silva, L.R.; Rivera, L.P.; Marcos-García, M.; garcía-Fraile, P.; Martínez-Molina, E.; Mateos, P.F.; Velázquez, E.; Andrade, P.; Rivas, R. Plants probiotics as a tool to produce highly functional fruits: The case of Phyllobacterium and vitamin $\mathrm{C}$ in strawberries. PLOS ONE 2015, 10, e0122281. [CrossRef]

34. Celador-Lera, L.; Flores-Félix, J.D.; Marcos-García, M.; Rivera, L.P.; Martinez-Hidalgo, P.; Menéndez, E.; Martinez-Molina, E.; Mateos, P.F.; Velázquez, E.; Rivas, R. Aplicación de bacterias endófiticas de vegetales cómo potenciales inoculantes de cultivos de zanahoria y lechuga. In Proceedings of the IV Congreso de Microbiología Industrial y Biotecnología Microbiana, Salamanca, Spain, 14-16 November 2012.

35. Flores-Félix, J.D.; Menéndez, E.; Marcos-García, M.; Mateos, P.F.; Martínez-Molina, E.; Velázquez, M.E.; Rivas, R. PGPR-based biofertilizers increase carrot production. New Biotechnol. 2016, 33, 430-431. [CrossRef]

36. Beringer, J.E. R factors transfer in Rhizobium leguminosarum. J. Gen. Microbiol. 1974, 84, 188-198. [CrossRef]

37. Zerbino, D.R.; Birney, E. Velvet: Algorithms for de novo short read assembly using de Bruijn graphs. Genome Res. 2008, 18, 821-829. [CrossRef] [PubMed]

38. Aziz, R.K.; Bartels, D.; Best, A.A.; DeJongh, M.; Disz, T.; Edwards, R.A.; Formsma, K.; gerdes, S.; glass, E.M.; Kubal, M.; et al. The RAST Server: Rapid annotations using subsystems technology. BMC Genom. 2008, 9, 75. [CrossRef] [PubMed]

39. Overbeek, R.; Olson, R.; Pusch, g.D.; Olsen, g.J.; Davis, J.J.; Disz, T.; Edwards, R.A.; gerdes, S.; Parrello, B.; Shukla, M.; et al. The SEED and the Rapid Annotation of microbial genomes using Subsystems Technology (RAST). Nucleic Acids Res. 2014, 42, D206-D214. [CrossRef]

40. Tatusova, T.; DiCuccio, M.; Badretdin, A.; Chetvernin, V.; Nawrocki, E.P.; Zaslavsky, L.; Lomsadze, A.; Pruitt, K.D.; Borodovsky, M.; Ostell, J. NCBI prokaryotic genome annotation pipeline. Nucleic Acids Res. 2016, 44, 6614-6624. [CrossRef]

41. Haft, D.H.; DiCuccio, M.; Badretdin, A.; Brover, V.; Chetvernin, V.; O’Neill, K.; Li, W.; Chitsaz, F.; Derbyshire, M.K.; gonzales, N.R.; et al. RefSeq: An update on prokaryotic genome annotation and curation. Nucleic Acids Res. 2018, 46, D851-D860. [CrossRef] [PubMed]

42. Aramaki, T.; Blanc-Mathieu, R.; Endo, H.; Ohkubo, K.; Kanehisa, M.; goto, S.; Ogata, H. KofamKOALA: KEGG ortholog assignment based on profile HMM and adaptive score threshold. Bioinformatics 2019, 19, 2251-2252. [CrossRef]

43. Grant, J.R.; Stothard, P. The CGView Server: A comparative genomics tool for circular genomes. Nucleic Acids Res. 2008, 36, W181-W184. [CrossRef]

44. Petkau, A.; Stuart-Edwards, M.; Stothard, P.; Van Domselaar, g. Interactive microbial genome visualization with gView. Bioinformatics 2010, 26, 3125-3126. [CrossRef]

45. Vincent, J.M. The cultivation, isolation and maintenance of Rhizobia. In A Manual for the Practical Study of the Root-Nodule Bacteria. IBP Handbook 15; Black Well Scientific Publications: Oxford, UK, 1970; pp. 1-13.

46. Marenda, M.; Zanardo, M.; Trovato, A.; Seno, F.; Squartini, A. Modeling quorum sensing trade-offs between bacterial cell density and system extension from open boundaries. Sci. Rep. 2016, 6, 39142. [CrossRef]

47. Augimeri, R.V.; Varley, A.J.; Strap, J.L. Establishing a role for bacterial cellulose in environmental interactions: Lessons learned from diverse biofilm-producing Proteobacteria. Front. Microbiol. 2015, 6, 1282. [CrossRef] [PubMed]

48. Mohan, R.; Benton, M.; Dangelmaier, E.; Fu, Z.; Chandra Sekhar, A. Quorum Sensing and biofilm formation in pathogenic and mutualistic plant-bacterial interactions. In Implication of Quorum Sensing System in Biofilm Formation and Virulence; Veera Bramhachari, P., Ed.; Springer: Singapore, 2018; pp. 133-160. 
49. Römling, U.; galperin, M.Y. Bacterial cellulose biosynthesis: Diversity of operons, subunits, products, and functions. Trends Microbiol. 2015, 23, 545-557. [CrossRef] [PubMed]

50. Ormeño-Orrillo, E.; Menna, P.; Almeida, L.G.; Ollero, F.J.; Nicolás, M.F.; Pains Rodrigues, E.; Shigueyoshi Nakatani, A.; Silva Batista, J.S.; Oliveira Chueire, L.M.; Souza, R.C.; et al. genomic basis of broad host range and environmental adaptability of Rhizobium tropici CIAT 899 and Rhizobium sp. PRF 81 which are used in inoculants for common bean (Phaseolus vulgaris L.). BMC Genom. 2012, 13, 735. [CrossRef] [PubMed]

51. Robledo, M.; Rivera, L.; Jiménez-Zurdo, J.I.; Rivas, R.; Dazzo, F.; Velázquez, E.; Martínez-Molina, E.; Hirsch, A.M.; Mateos, P.F. Role of Rhizobium endoglucanase CelC2 in cellulose biosynthesis and biofilm formation on plant roots and abiotic surfaces. Microb. Cell Factories 2012, 11, 125. [CrossRef]

52. Downie, J.; gonzález, J. Cell-to-Cell communication in rhizobia: Quorum Sensing and Plant Signaling. In Chemical Communication among Bacteria; Winans, S., Bassler, B., Eds.; ASM Press: Washington, DC, USA, 2008; pp. 213-232.

53. Calatrava-Morales, N.; McIntosh, M.; Soto, M.J. Regulation mediated by N-Acyl homoserine lactone quorum sensing signals in the Rhizobium-Legume symbiosis. Genes 2018, 9, 263. [CrossRef] [PubMed]

54. Ling, J.; Zhou, L.; Wu, g.; Zhao, Y.; Jiang, T.; Liu, F. The AHL Quorum-sensing System negatively regulates growth and autolysis in Lysobacter brunescens. Front. Microbiol. 2019, 10, 2748. [CrossRef]

55. Vitousek, P.M.; Porder, S.; Houlton, B.Z.; Chadwick, O.A. Terrestrial phosphorus limitation: Mechanisms, implications, and nitrogen-phosphorus interactions. Ecol. Appl. 2010, 20, 5-15. [CrossRef]

56. Rodríguez, H.; Fraga, R.; gonzalez, T.; Bashan, Y. genetics of phosphate solubilization and its potential applications for improving plant growth-promoting bacteria. Plant Soil 2006, 287, 15-21. [CrossRef]

57. Egamberdieva, D.; Wirth, S.J.; Alqarawi, A.A.; Abd Allah, E.F.; Hashem, A. Phytohormones and beneficial microbes: Essential components for plants to balance stress and fitness. Front. Microbiol. 2017, 8, 2104. [CrossRef]

58. Duca, D.R.; glick, B.R. Indole-3-acetic acid biosynthesis and its regulation in plant-associated bacteria. Appl. Microbiol. Biotechnol. 2020, 104, 8607-8619. [CrossRef] [PubMed]

59. Duca, D.; Lorv, J.; Patten, C.L.; Rose, D.; glick, B.R. Indole-3-acetic acid in plant-microbe interactions. Antonie Leeuwenhoek 2014, 106, 85-125. [CrossRef] [PubMed]

60. Carson, K.C.; Meyer, J.M.; Dilworth, M.J. Hydroxamate siderophores of root nodule bacteria. Soil Biol. Biochem. 2000, 32, 11-21. [CrossRef]

61. Sahin, U.; Ekinci, M.; Kiziloglu, F.M.; Yildirim, E.; Turan, M.; Kotan, R.; Ors, S. Ameliorative effects of plant growth promoting bacteria on water-yield relationships, growth, and nutrient uptake of lettuce plants under different irrigation levels. Hortscience 2015, 50, 1379-1386. [CrossRef]

62. Cipriano, M.A.; Lupatini, M.; Lopes-Santos, L.; da Silva, M.J.; Roesch, L.F.; Destéfano, S.A.; Freitas, S.S.; Kuramae, E.E. Lettuce and rhizosphere microbiome responses to growth promoting Pseudomonas species under field conditions. FEMS Microbiol. Ecol. 2016, 92, fiw197. [CrossRef]

63. Venancio, W.S.; Marcolino gomes, J.; Shigueyoshi Nakatani, A.; Hungria, M.; Silva Araujo, R. Lettuce production under reduced levels of $N$-fertilizer in the presence of plant growth-promoting Bacillus spp. bacteria. J. Pure Appl. Microbiol. 2019, 13, 1941-1952. [CrossRef]

64. Vetrano, F.; Miceli, C.; Angileri, V.; Frangipane, B.; Moncada, A.; Miceli, A. Effect of bacterial inoculum and fertigation management on nursery and field production of lettuce plants. Agronomy 2020, 10, 1477. [CrossRef] 